\title{
Fuzzy Logic based MPPT Control of Hybrid Power Generation System
}

\author{
T.Shanthi \\ Dept. of EEE \\ Kumaraguru College of Tech \\ Coimbatore
}

\author{
A.S.Vanmukhil \\ Dept. of EEE \\ Kumaraguru College of Tech \\ Coimbatore
}

\begin{abstract}
This paper describes the modeling of integrated hybrid renewable energy system. The wind and solar are used as input sources for the hybrid system. The proposed system involves the design of photovoltaic (PV) and wind energy conversion system (WECS). The system is designed for constant wind speed and varying solar irradiation and insolation. Maximum power point tracking (MPPT) algorithm is used to extract the maximum power from PV array. The integration of two input sources is done by current-sourceinterface multiple-input (MI) cuk converter. Fuzzy logic controller is used to control the duty cycle of one of the converter switch thereby extracting the maximum power from solar array. The system consists of photovoltaic (PV) array, wind energy conversion system (WECS), multiple input current- source-interface cuk converter, voltage source inverter (VSI), LC filter and three phase load. The entire proposed system has been modeled and simulated using MATLAB/simulink software. The simulation results show that the proposed system generates a power of $30 \mathrm{KW}$ at low cost.
\end{abstract}

\section{Keywords}

Photovoltaic system, Wind energy conversion system, power conversion, MPPT, Fuzzy logic, MI cuk converter.

\section{INTRODUCTION}

Renewable energy sources have attracted wide attention because of its abundant nature. Wind power can be easily captured by generators with high capacity. It is one of the promising and clean energy sources. Photovoltaic (PV) power is global and it can be extracted without using rotational generators. PV power is also another clean energy resource. PV and wind power are complementary in nature. During sunny days the winds will be weak and strong winds blow during nights and cloudy days. Hence, to get an uninterrupted supply wind-PV hybrid power generation system [1] [2] can be implemented. It provides higher reliability and continuous supply of power from any one of the resources either solar or wind. The wind energy conversion system consists of wind turbine and PMSG. WECS converts the mechanical energy into electrical energy. Wind turbine gives mechanical output which is converted into electrical energy by permanent magnet synchronous (PMSG) generator. It is a directly driven generator. It does not require any dc field excitation. The ac output from WECS is converted into dc by three phase diode rectifier. This paper uses a current-source-interface multiple input cuk converter [4] for integration of PV and wind resources. The MI cuk converter reduces unnecessary redundancy of additional parallel converters in each input source. The MI cuk converter is a DC-DC converter [14]. It provides decentralized control. It has two switches. Since the wind speed is constant, the duty cycle of one of the switches of the converter corresponding to PV input is controlled by fuzzy logic controller [19]. The inputs to the fuzzy logic controller are provided Maximum power point tracking algorithm (MPPT). The output voltage of VSI is regulated by PI controller. The gating pulses to VSI are generated by the PI controller.

The paper is organized as follows. The overall architecture of the fuzzy logic based [16][17] MPPT system and the modeling of different components of the system are described in section II and section III respectively. The control strategies of the proposed system are explained in section IV and the simulation results of the proposed system are included in section V.

\section{PROPOSED SCHEME}

Fig.1. illustrates the overall block diagram of the proposed system with wind and PV resources. The main energy sources of the hybrid system [2] [3] are transformed into wind generator and PV modules. A multiple input cuk converter allows the integration of the wind and PV energy resources because this type of converter is more effective in maximum power point tracking (MPPT) in PV modules and input current control method used in the proposed system .MICS were chosen for their cost effective and flexible method of interfacing the two renewable energy sources.

The output voltage from the PV module is DC. Since the output voltage of the wind generator is ac, three-phase diode rectifier converts it into dc voltage. The dc voltages from the $\mathrm{PV}$ module and three phase diode rectifier are given as inputs to the switches of the cuk converter. The dc voltage is again converted into ac by PWM inverter. The output voltage from the inverter is given to the LC filter to reduce the harmonic voltages in the ac load.

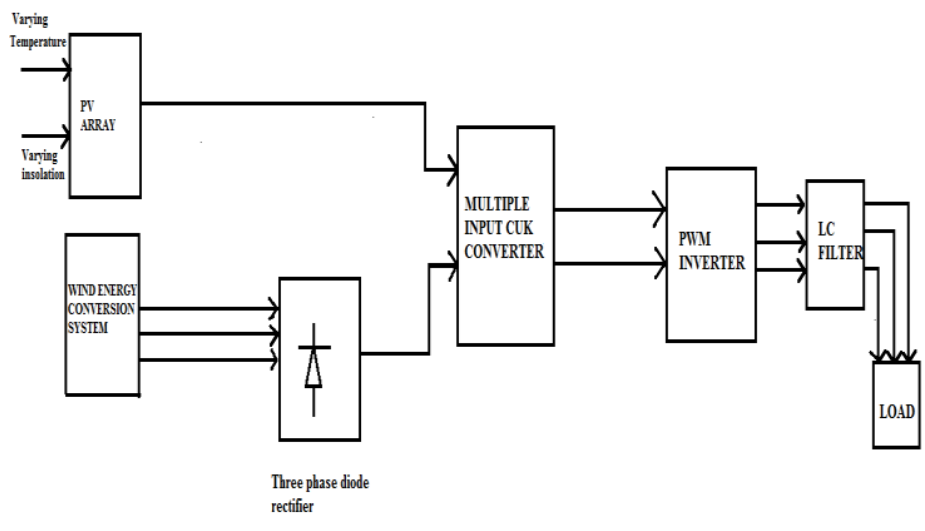

Fig 1: Power circuit of the proposed system 


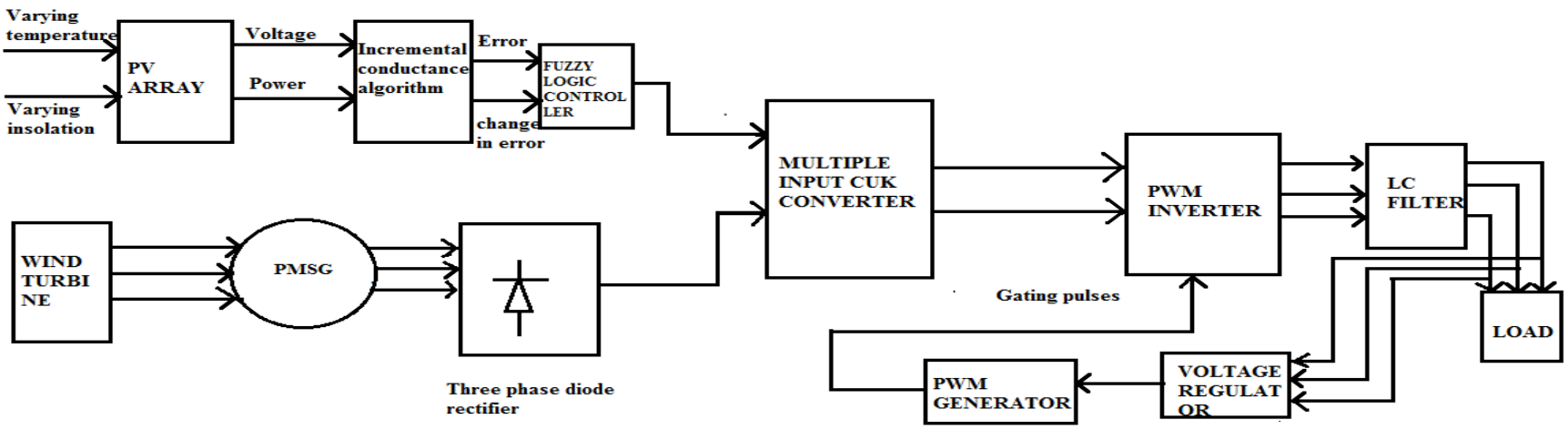

Fig 2: Control structure of the proposed system

\section{MODELING OF COMPONENTS OF THE PROPOSED SYSTEM}

This section describes the modeling of the major components used in the hybrid system whose results are discussed in section V. This paper uses a wind model present in the MATLAB/Simulink library. It consists of wind turbine and PMSG. The permanent magnet synchronous generator is directly driven without any gear. The mechanical output of the wind turbine is converted into electrical output by PMSG. Hence the output of the wind model is three phase ac voltage. It is converted into DC by three phase diode rectifier.

\subsection{Wind Turbine Model}

The wind turbine model used in the hybrid system [6][7] gives mechanical torque as the output( $\mathrm{Tm})$ which drives a wind generator. The inputs to the wind turbine are wind speed (Vwind), pitch angle ( $\beta$ ), and the rotor speed of the permanent magnet synchronous generator. The hybrid system proposed in this paper is designed for constant wind speed. The mechanical power $(\mathrm{Pm})$ Captured by the blades of a wind turbine is given by the following equation

$$
P m=\frac{1}{2} C p(\beta, \lambda) \rho \pi R^{2} V w i n d{ }^{3}
$$

Where $\mathrm{Cp}$ is a rotor power coefficient, $\beta$ is a blade pitch angle, $\lambda$ is a tip-speed ratio (TSR), $\rho$ is an air density, $\mathrm{R}$ is the radius of a wind turbine blade, and $\mathrm{V}$ wind is a wind speed. The rotor power coefficient is defined by the fraction of the available wind power that can be transformed into mechanical power by the rotor. The rotor power coefficient $(\mathrm{Cp})$ depends on the blade aerodynamics which is a function of blade pitch angle $(\beta)$ and TSR $(\lambda)[7]$. The type of wind turbine rotor is also another factor affecting the rotor power coefficient $(\mathrm{Cp})$. The TSR $(\lambda)$ is a function of rotor speed and wind speed.

$$
\lambda=\omega m R / V \text { wind } \lambda^{3}
$$

Where $\omega \mathrm{m}$ is the rotor speed of a wind turbine. The aerodynamic input torque $(\mathrm{Tm})$ with which the generator is driven is given by the equation

$$
T m=C p(\beta, \lambda) \rho \pi R^{5} / 2 \lambda^{3}
$$

$\mathrm{Tm}=\mathrm{Pm} / \omega \mathrm{m}$.

A constant pitch angle of $\left(\beta=0^{\circ}\right)$ is used because the torque is maximum only when the pitch angle of the blade is $0^{\circ}$.
Table.1.Parametersand Specifications of the Wind Turbine Model

\begin{tabular}{|l|c|c|}
\hline Parameter name & Value & Unit \\
\hline Rated power & 22 & $\mathrm{KW}$ \\
\hline Air density & 1.225 & $\mathrm{Kg} / \mathrm{m}^{3}$ \\
\hline Rated wind speed & 12 & $\mathrm{~m} / \mathrm{s}$ \\
\hline Blade pitch angle & 0 & Degree \\
\hline
\end{tabular}

Table.2.Specifications of the PMSG Model

\begin{tabular}{|l|c|c|}
\hline Parameter name & Value & Unit \\
\hline Rated power & 22 & KW \\
\hline Rated line voltage & 600 & V \\
\hline $\begin{array}{l}\text { Stator phase } \\
\text { inductance }\end{array}$ & 0.012 & p.u \\
\hline $\begin{array}{l}\text { Stator phase } \\
\text { resistance }\end{array}$ & 0.119 & p.u \\
\hline $\begin{array}{l}\text { Magnetizing } \\
\text { inductance }\end{array}$ & 4.366 & p.u \\
\hline
\end{tabular}

\subsection{PV System Model}

A PV cell can be represented by equivalent circuit shown in Fig. 2.The characteristics of this PV cell can be obtained using standard equation.

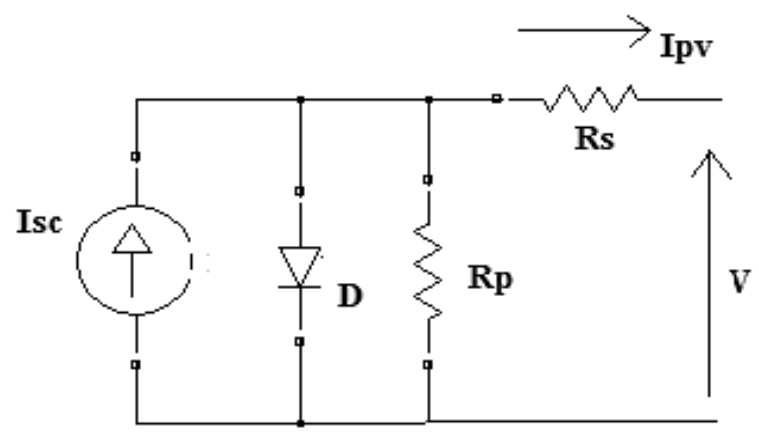

Fig 3: Solar cell model using single diode with $\mathbf{R s}$ and $\mathbf{R f}$ 
This cell model includes a current source which depends on solar radiation and cell temperature, a diode in which the inverse saturation current Io depends mainly on the operating temperature, a series resistance Rs and the shunt resistance Rp which takes into account the resistive losses.

$$
\begin{aligned}
& I p v=N p I s c-N s I o\left\{\exp \left(\frac{q(V p v+I p v R s)}{N s A K T}\right)-1\right\}- \\
& V p v+\left(\frac{I p v R s}{R p}\right)
\end{aligned}
$$

Ipv - Photovoltaic current

Io -Saturation Current

Ns - No of cells connected in series

$\mathrm{Np}$ - No of cells connected in parallel

T-Temperature of $\mathrm{p}-\mathrm{n}$ junction

K-Boltzmann constant

q-electron charge

Rs-equivalent series resistance of the array

$\mathrm{Rp}$-equivalent parallel resistance of the array.

A-diode ideality factor

The nonlinear equation depends on the incident solar irradiation, the cell temperature, and on the reference values[2]. These reference values are generally provided by manufacturers of PV modules for specified operating conditions such as STC for which the irradiance is $1000 \mathrm{~W} / \mathrm{m} 2$ and the cell temperature is $25^{\circ} \mathrm{C}$.

The value of the parallel resistance is generally high and hence neglected to simplify the model [3]. The rated power of the PV model used is nearly $22 \mathrm{KW}$. The simulated PV array [8][9] is composed of four parallel cells and three hundred series cells which provides an output voltage of $230 \mathrm{~V}$ and current of $10 \mathrm{~A}$ at the maximum power point respectively.

\subsection{CSI Converter}

Among the multiple input current source interface converters [10][11] MI cuk converter and MI SEPIC converter can be used in the proposed hybrid system. But MI cuk converter [12]is best suited for the proposed hybrid because it provides nearly continuous input current waveforms due to their current source interface input legs. The MI cuk converter is similar to MI SEPIC converter [13] except the fact that the output voltage of the converter is inverted.

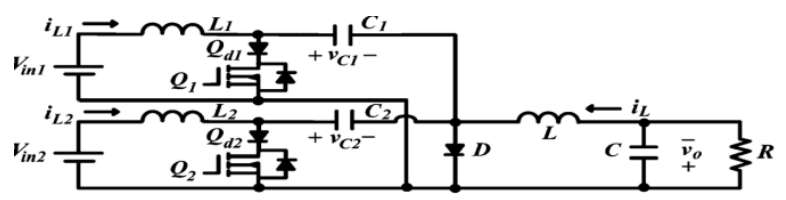

Fig 4 : MI cuk DC-DC converter [10]

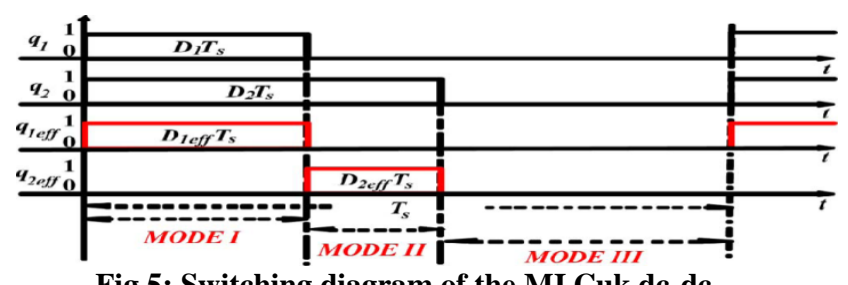

Fig 5: Switching diagram of the MI Cuk dc-dc converter[14].

The Fig.4 explains the circuit diagram of the MI Cuk DC converter [13]. It consists of two input voltage sources Vin1 and Vin2 .In the hybrid system proposed in this paper the two input sources are wind and solar energy sources respectively.

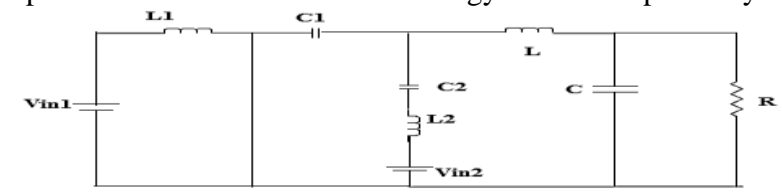

(a)

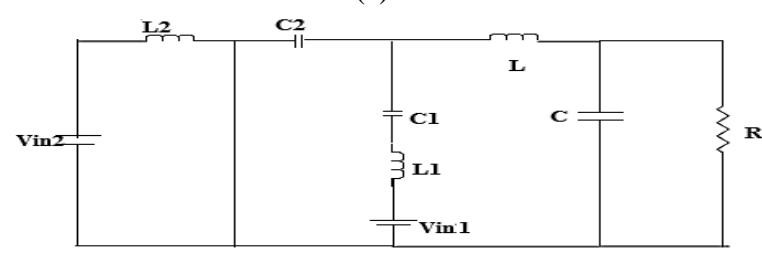

(b)

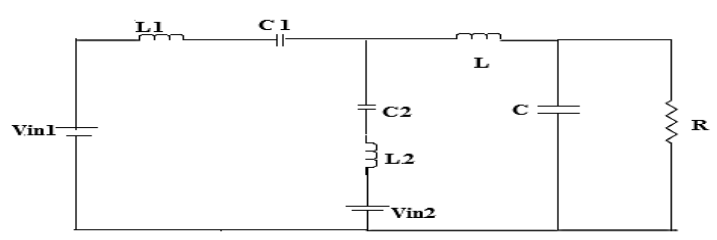

(c)

Fig 6: Operational modes of the cuk dc-dc converter a) Mode I (Only Q1 conducts current) b) Mode II (onlyQ2 conducts current) (c) only diode $D$ conducts current [14].

Fig.5 illustrates the switching diagram of the MI cuk converter. If the converter is assumed to be operated in continuous conduction mode, the steady state operation of the circuit can be explained based on the three following operational modes

\subsubsection{Mode $1(0<t<D 1 T s)$}

In this mode of operation the first input source (Vin1) i.e. wind in this paper is assumed to be higher than the second input source (Vin2) i.e. solar. In this mode the switches Q1 and Q2 are turned ON but only Q1 conducts current since D2 is reverse biased. The diode $\mathrm{D}$ is also reverse biased.

\subsubsection{Mode $2(D 1 T s<t<D 2 T s)$}

In this mode of operation the switch Q2 is turned ON because diode D2 is forward biased .The diode D is still reverse biased.

\subsubsection{Mode 3(D2Ts $<t<T s)$}

In this mode of operation the diode D only conducts. The other switches are turned off in this mode.

The steady state output voltage of the MI cuk converter is

$V o=(D 1 \operatorname{Vin} 1+D 2 e f f \operatorname{Vin} 2) /(1-D 2)$

Vin1 - First input source i.e. wind

Vin2- Second input source i.e. solar

D1- Duty cycle of switch Q1

D2- Duty cycle of switch Q2

D2eff - Effective duty cycle of switch Q

\section{CONTROL STRATEGIES}

\section{1 .MPPT of PV using Fuzzy Controller}

The output voltage of the PV module varies with varying temperature and varying insolation [15]. So the output power also varies. To extract the maximum power from the modules MPPT algorithm is used. The MPPT algorithm used in this paper is incremental conductance [16]. This algorithm uses 
the Voltage and power from the PV modules and calculates the error value and change in error values using

Error $(\mathrm{k})=\mathrm{P}(\mathrm{k})-\mathrm{P}(\mathrm{k}-1) / \mathrm{V}(\mathrm{k})-\mathrm{V}(\mathrm{k}-1)$

Change Error $(\mathrm{k})=$ Error $(\mathrm{k})$-Error $(\mathrm{k}-1)$

Where $\mathrm{P}(\mathrm{k})$ is the instant power of the PV system.

The input error $(\mathrm{k})$ shows whether the operating point is located to the left or right of the MPP at the instant $\mathrm{k}$. The change in error $(\mathrm{k})$ indicates the movement of operating point. The error and change in error are given as inputs to the fuzzy logic controller (FLC). The FLC [16] examines the output PV power at each instant (time $(\mathrm{k})$ ), and determines the change in power relative to voltage $(\mathrm{dp} / \mathrm{dv})$.If $\mathrm{dp} / \mathrm{dv}$ is greater than zero the controller change the duty cycle of pulse width modulation until the power is maximum or $\mathrm{dp} / \mathrm{dv}=0$.If the value is less than zero then the controller changes the duty cycle to decrease the voltage until the power is maximum. The fuzzy logic controller's output is given to the PWM generator. The pulses from the PWM generator are fed as duty cycle to the switch corresponding to solar input of the MI cuk converter.

The fuzzy inference is carried out using Mamdani method. The

three basic functions of FLC are Fuzzification, Rule base and Defuzzification[16][17].

\subsubsection{Fuzzification}

Fuzzification includes the design of input and output membership functions. These functions are designed based on the prior knowledge. The two input and one output membership functions are illustrated in fig.7,8and 9 respectively.

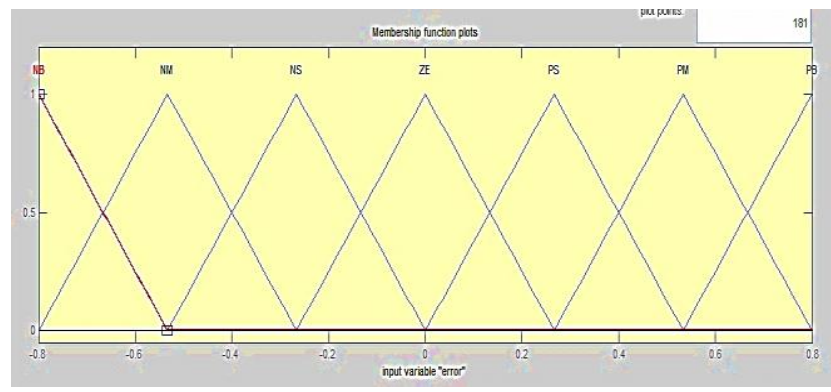

Fig 7: Membership function of error

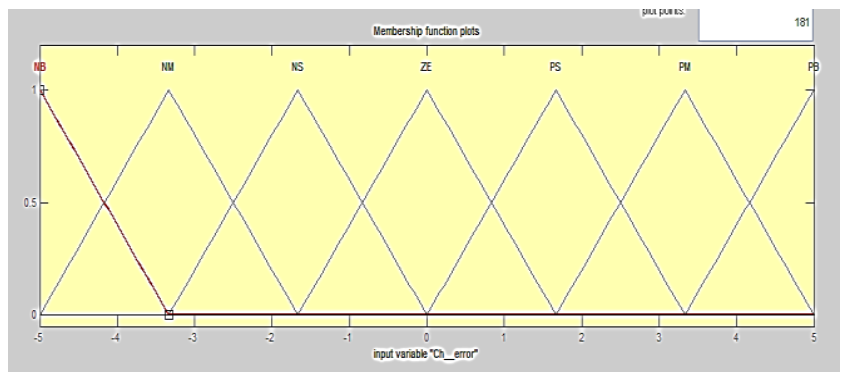

Fig. 8: Membership function of change in error

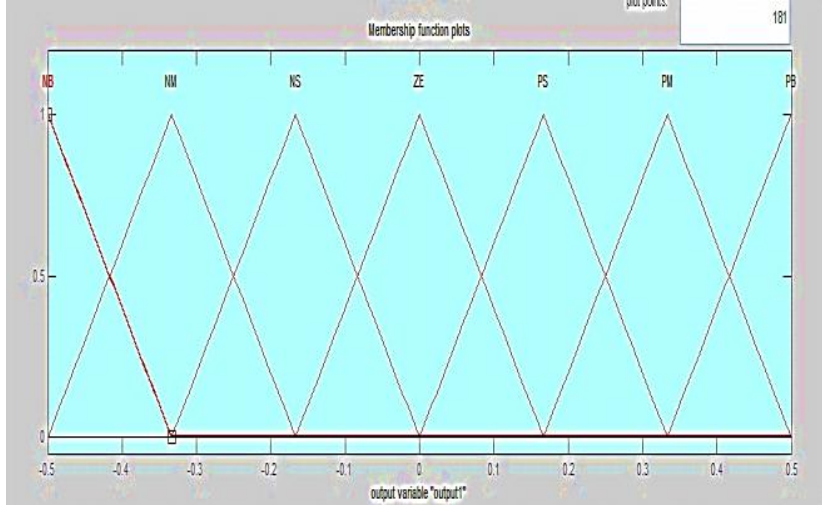

Fig 9: Membership function of Duty ratio (D)

\subsubsection{Rule base}

The rule base defines the relationship between input and output membership functions. The control rules[18][19] are evaluated by the inference mechanisms.Fig.10. Shows the rule base of fuzzy logic controller the linguistic variables used are NB-Negative Big NM-Negative Medium NS - Negative small ZE- Zero PS- positive small PM-positive medium PB positive Big.

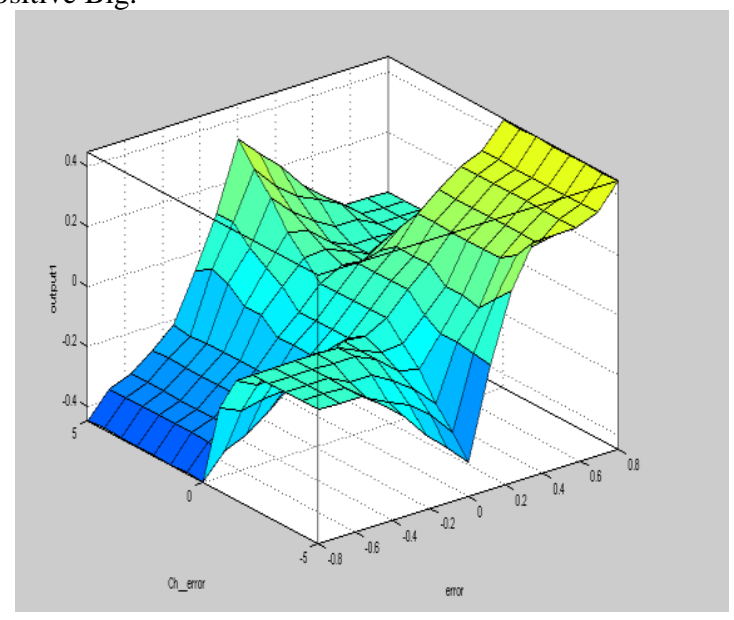

Fig 10: Rule surface of FLC

\subsubsection{Defuzzification}

The defuzzification uses the Centre of gravity to compute the output of the fuzzy logic controller .The output is nothing but duty cycle.

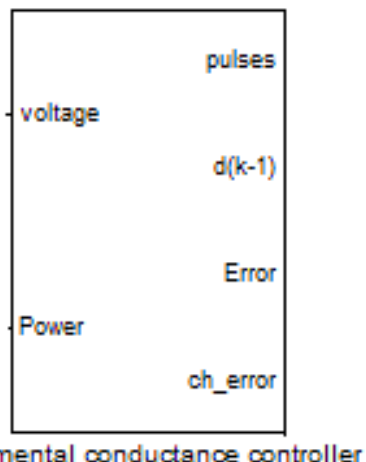




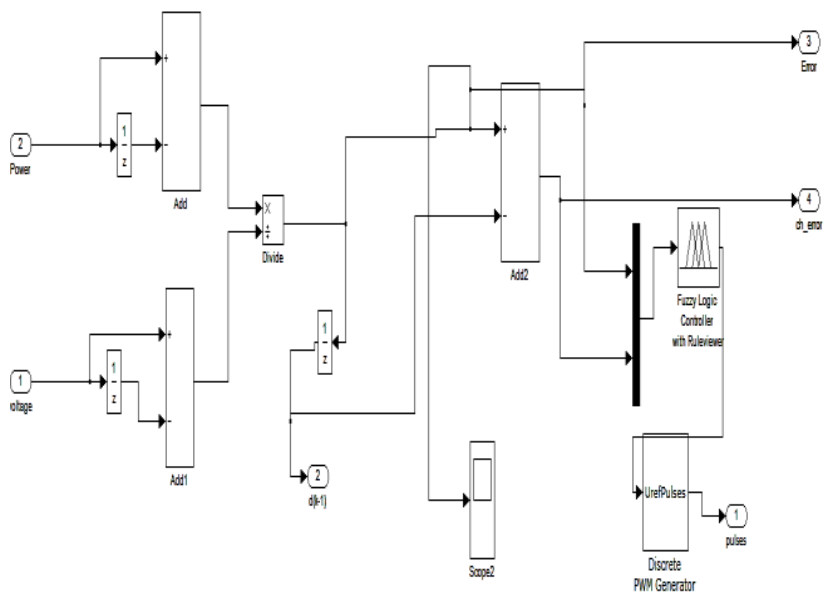

Fig 11: Incremental conductance algorithm using FLC

\subsection{VOLTAGE REGULATION}

The output voltage of the hybrid system is regulated using PI controller. The output voltage is compared with reference voltage and the error signal is given as input to the PI controller. The PI controller minimizes the error and the output of the PI controller is given to the discrete PWM generator. The output pulses are given as gating signals to the VSI.

\section{RESULTS AND DISCUSSIONS}

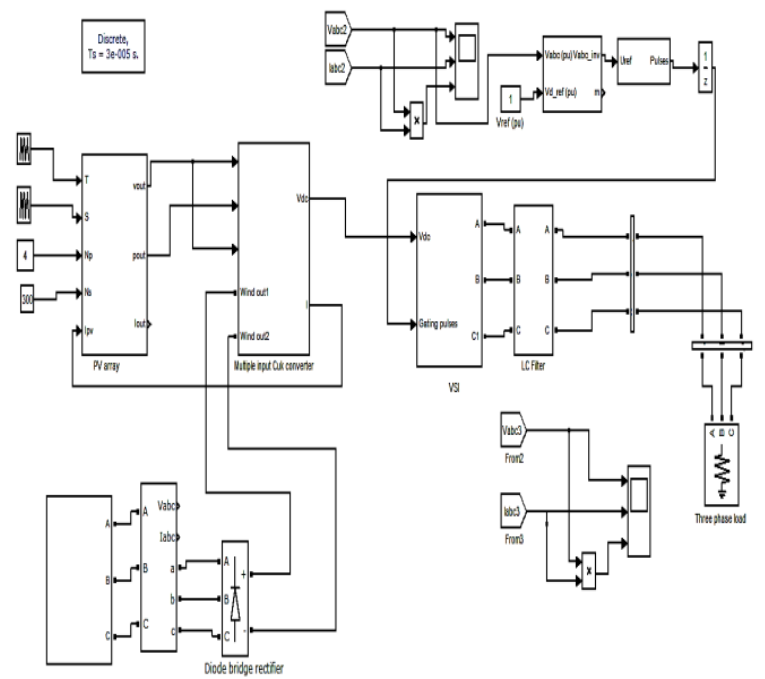

Fig 12:Overall simulation diagram of the proposed system

Fig.12 shows the overall simulation diagram of $30-\mathrm{KW}$ Wind/solar hybrid power system. The wind turbine is modeled using the equations (1) (2)and (3). The specifications of the wind turbine and PMSG are specified elaborately in Tables 1 and 2 respectively. Fig. 11 explains the controller which implements the incremental conductance control which is used to track the MPPs of solar energy as discussed in section 4.1. The MI cuk converter is modeled with built in components of MATLAB simulink/simpower systems.

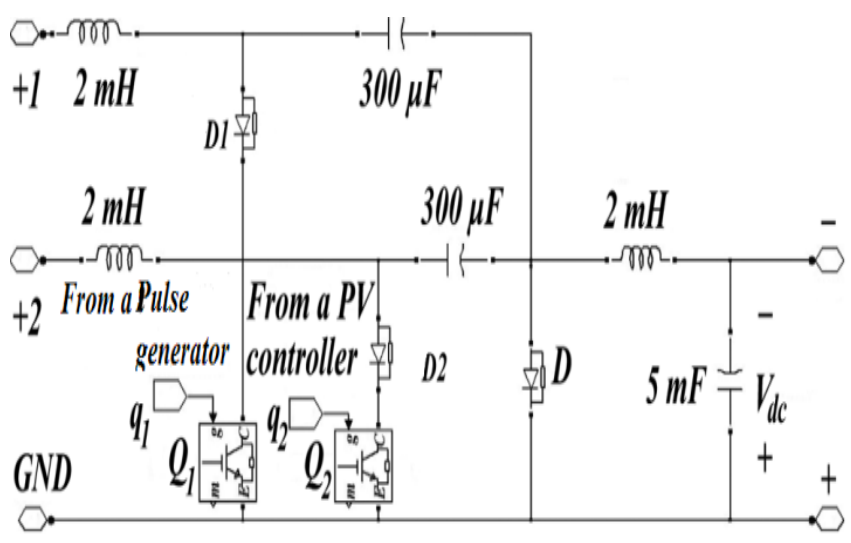

Fig 13: Schematic of the MI cuk converter.

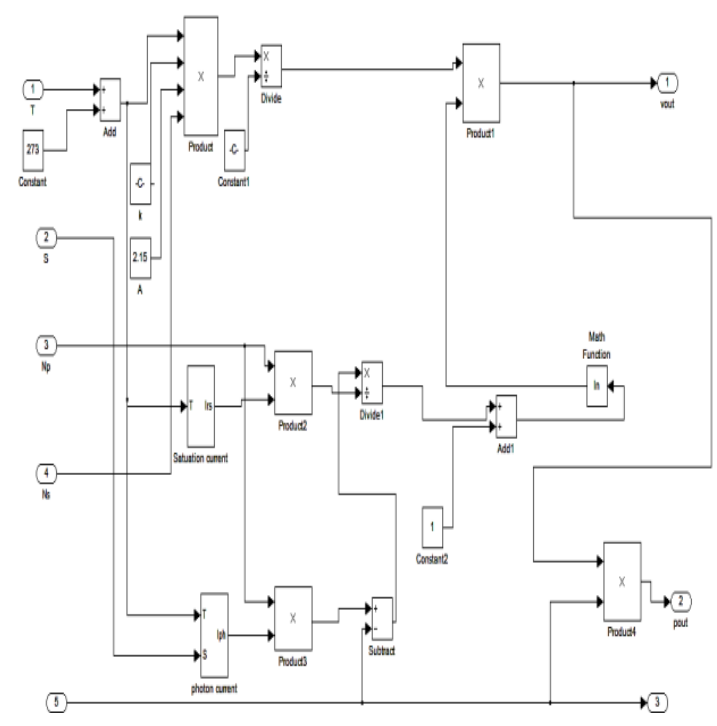

Fig 14: Simulink model of a PV array

Fig. 13 shows the schematic of MI cuk converter modeled with MATLAB/ Simulink. The internal models of a PMSG, three phase diode bridge rectifier and a PWM inverter in MATLAB simulink/simpowersystems is used for this study. The simulink model shown in fig 14 is the simulink model of PV array used for simulation.

\subsection{Wind turbine performance}

The wind turbine modeled using the equations (1), (2) and (3) runs at a constant speed of $12 \mathrm{~m} / \mathrm{s}$ as shown in fig 15 (a).The PMSG model in the simulink library is used in this paper. The rotor power coefficient $(\mathrm{Cp})$ is kept constant at a maximum value of 0.44 .The specifications of the wind turbine and PMSG are already mentioned in section 3 . 


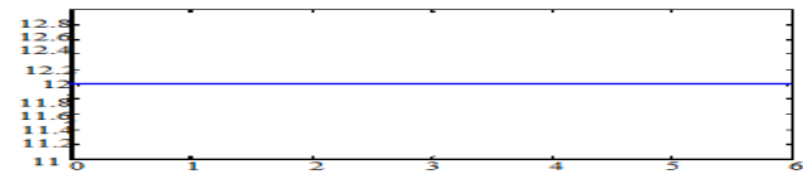

(a)

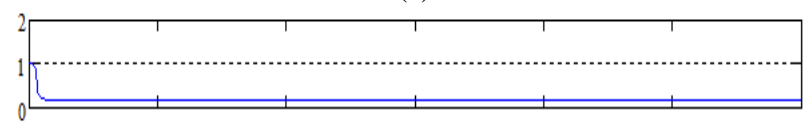

(b)

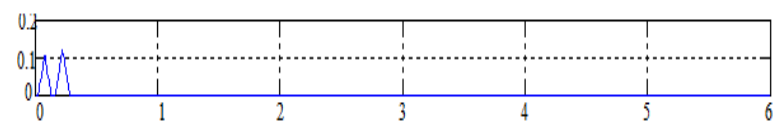

(c)

Fig 15: (a) wind speed in $\mathbf{m} / \mathrm{s}$ (b) Reactive powerin p.u (c) pitch angle in degrees.

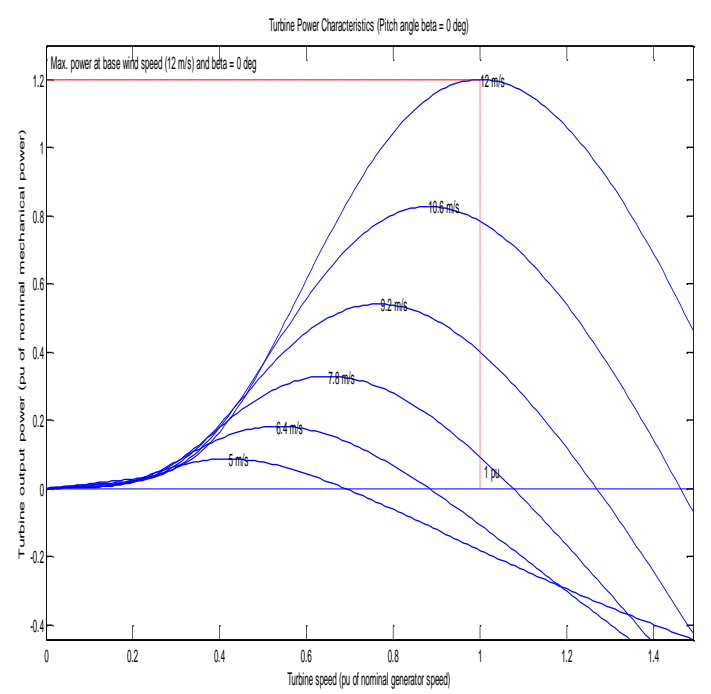

Fig 16: Wind turbine output characteristics

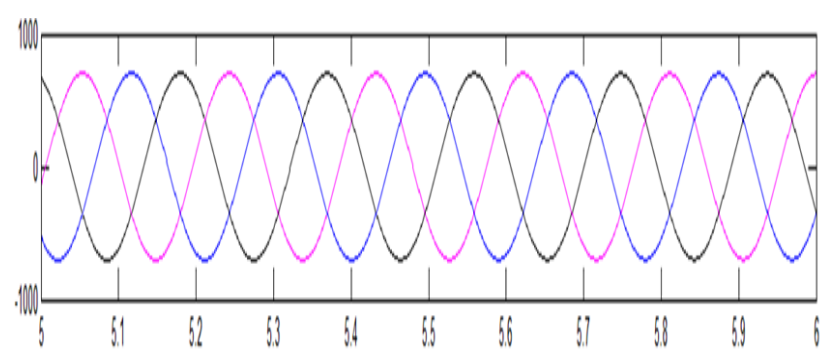

(a)

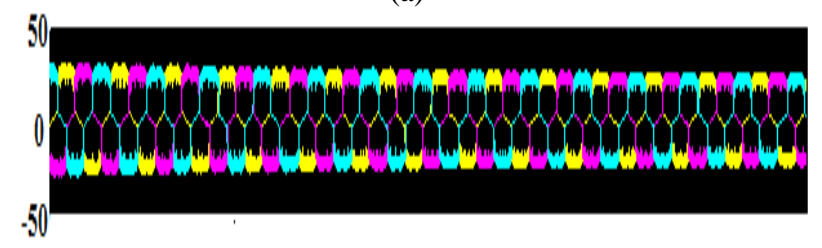

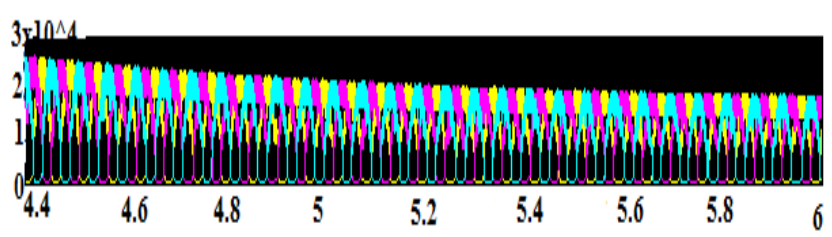

(b)

Time(s)

Fig 17: Wind turbine performance (a) Wind turbine output voltage (b) Turbine output current and output power.

Wind turbine output characteristics which have been simulated for different wind velocities are shown in fig. 16 . The wind turbine modelled using the equations provide an output voltage of $600 \mathrm{~V}$ and an output power of nearly $22 \mathrm{KW}$ as illustrated in fig 17.

\section{2 . Control performance of the PV modules}

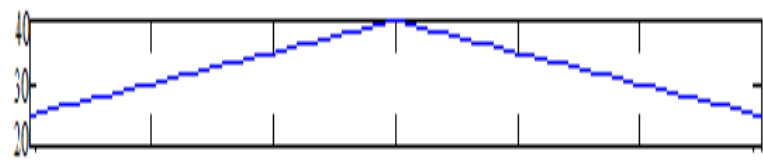

(a)

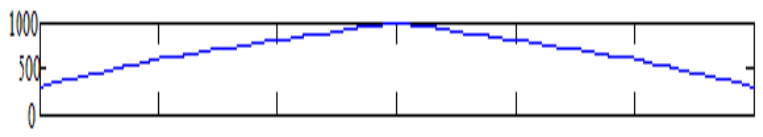

(b)

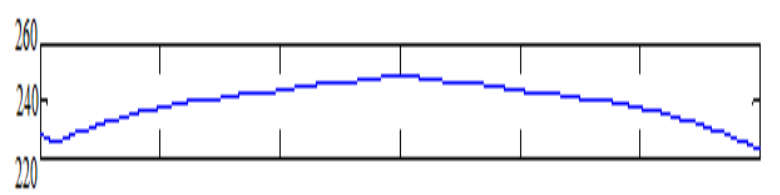

(c)

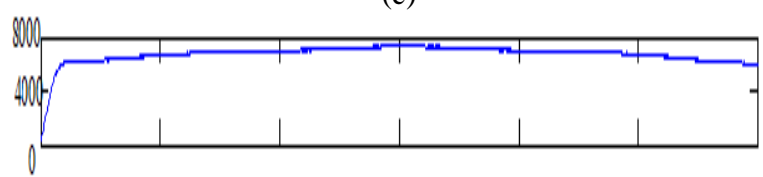

(d)

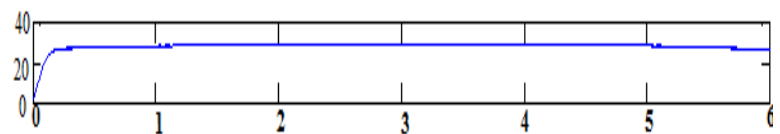

(e)

Time(s)

Fig 18: PV module control performance (a) PV module varying temperature (b) solar irradiance(c)PV output voltage (d)PV output power(e) PV module output current.

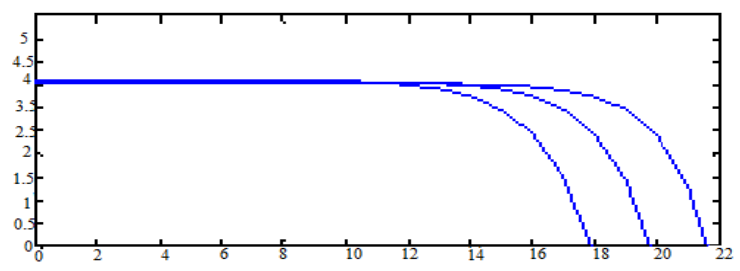




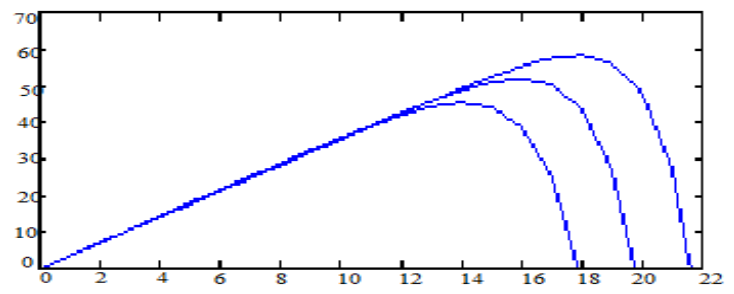

(a)
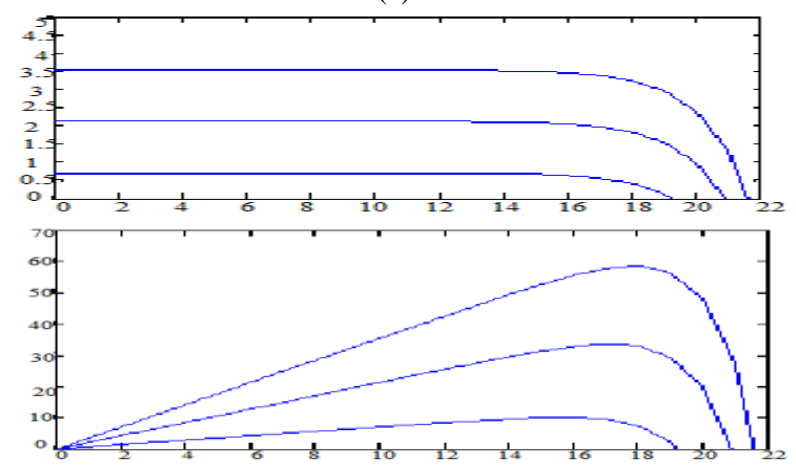

(b)

Fig 19: (a) I-V and P-V Characteristic for constant irradiance varying temperature and constant irradiation

(b) I-V and P-V characteristic for varying irradiance constant temperature

The PV module is simulated for varying temperature and irradiance. The output voltage varies with both of these parameters. Fig.19 illustrates the characteristics of PV array for varying temperature and irradiance. The PV modules operating point well follows the MPP when the solar irradiance and temperature varies as shown in fig.18 (a) and (b).The PV controller tracks the maximum power of $8 \mathrm{KW}$ and an output voltage of $230 \mathrm{~V}$ regardless of varying temperature and insolation. The fig 18 shows the control strategy discussed in section 4.1 is adequate one for hybrid system with MI CSI.

\subsection{Control performance of the MI cuk converter}

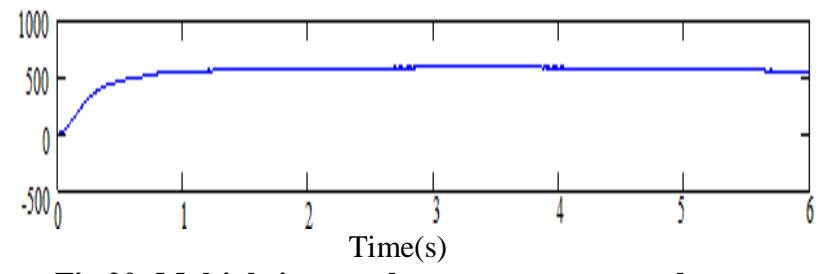

Fig 20: Multiple input cuk converter output voltage

The output voltage of the MI cuk converter shown in fig.20 is found to be settled at nearly $515 \mathrm{~V}$.

\subsection{Inverter results with load}

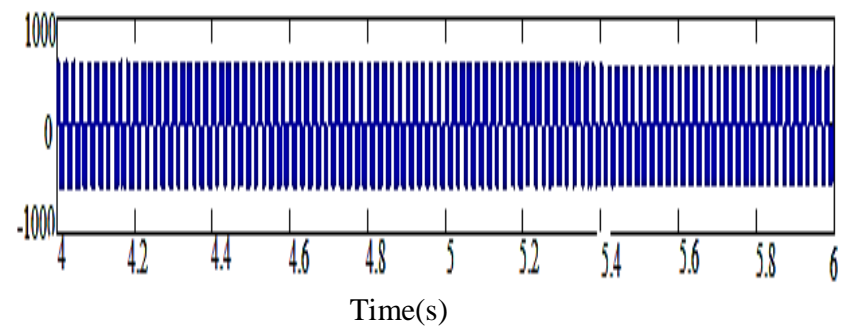

Fig 21: output voltage of PWM inverter

The output voltage of the PWM inverter is settling at $500 \mathrm{~V}$ as shown in fig. 21

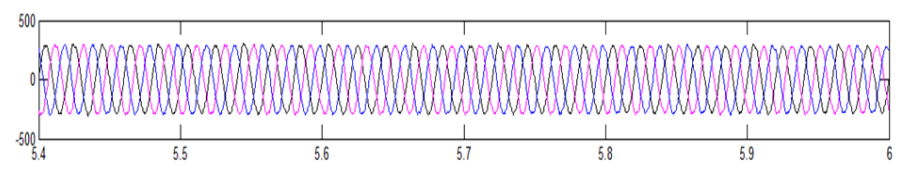

(a)

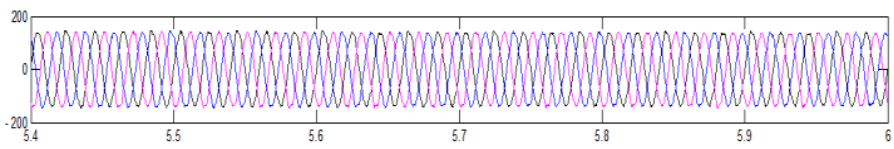

(b)

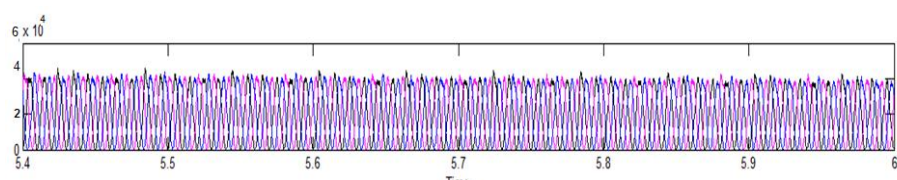

(c)

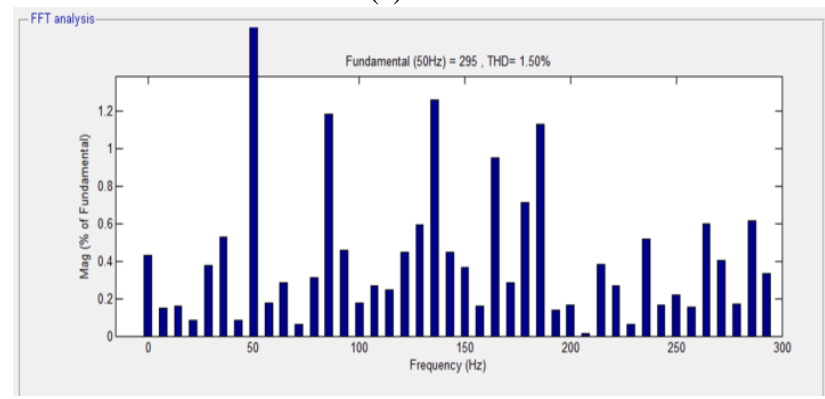

(d)

Time(s)

Fig 22:(a)Load Voltage(b)Load current(c)Load power (d)Local three-phase ac voltage THD

The output voltage,output current and output power voltage harmonic distortion waveforms of the proposed hybrid system are measured across the three phase load and given in fig.22. The Table III shows the simulated results of the proposed hybrid system.

Table .3.Simulated Results of Hybrid System

\begin{tabular}{|c|c|}
\hline Parameters & Values \\
\hline Load Voltage & $300 \mathrm{~V}$ \\
\hline Load current & $0.1 \mathrm{KA}$ \\
\hline Output power & $30 \mathrm{KW}$ \\
\hline THD & $1.51 \%$ \\
\hline
\end{tabular}




\section{CONCLUSION}

This paper presents the modelling of hybrid system consisting of wind and solar. These renewable energy sources are integrated through a MI current source interface dc-dc converter. These diverse micro energy resources can improve the hybrid system performance. The power converter proposed in this paper is designed at low cost to avoid redundancy of components.

A $30-\mathrm{kW}$ wind/solar hybrid model was developed using MATLAB/simulink/simpowersystems. The wind generator used in this proposed hybrid system runs at a constant speed.The PV array uses an incremental conductance algorithm and a fuzzy logic controller to capture the maximum power.

In contrast to the previous works, this paper has explored the wide performance of the hybrid system with fuzzy controller and MI dc-dc converter.The results discussed in section V proves that the control strategy proposed in this paper is feasible while developing a hybrid system with CSI MI dc-dc converter which can reduce its production costs.

\section{ACKNOWLEDGMENTS}

T.Shanthi received her bachelor's degree from Institute of Road and Transport Technology, Erode, Tamilnadu, India in Electrical and Electronics Engineering during 1999. She received her Master's degree from National Institute of Technology, Tiruchirappalli, India during 2007. She is currently working as Assistant Professor at the department of Electrical and Electronics Engineering in Kumaraguru College of Technology, Coimbatore, India. Her area of interest includes Power system optimization, Distributed generation, Power Electronics and Smart Grid.

A.S.Vanmukhil received the B.E.degree from Sri Ramakrishna Institute of Technology, Coimbatore (Anna University, Chennai, India) in 2010. She received her Master's degree from Kumaraguru college of Technology, Coimbatore, India during 2013. Her area of interest includes Power electronics, Renewable energy and Digital Electronics.

\section{REFERENCES}

[1] C.Liu, K.T.Chau and Z.Xiaodong, "An efficient windphotovoltaic hybrid generation system using doubly excited permanent-magnet brushless machine," IEEE Trans.Ind.Electron., vol.57, no.3, pp.831-839, Mar.2010.

[2] S.-K. Kim, J.-H. Jeon, C.-H. Cho, J.-B. Ahn, and S.-H. Kwon, "Dynamic modelling and control of a gridconnected hybrid generation system with versatile power transfer," IEEE Trans. Ind. Electron., vol.

55, no. 4, pp. 1677-1688, Apr. 2008

[3] E. Muljadi and J. T. Bialasiewicz, "Hybrid power system with a controlled energy storage," in Proc. IEEE 29th IECON, 2003, vol. 2, pp.1296-1301

[4] G. R.Walker and P. C. Senia, "Cascaded DC-DC converter connection of photovoltaic modules," IEEE Trans. Power Electron., vol. 19, no. 4,pp. 1130-1139, Jul. 2004
[5] B. M. T. Ho and S.-H. Cheng, "An integrated inverter with maximum power tracking for grid-connected PV systems," IEEE Trans. Power Electron., vol. 20, no. 4, pp. 953-962, Jul. 2005.

[6] P. M. Anderson and A. Bose, "Stability simulation of wind turbine systems," IEEE Trans. Power Appl. Syst., vol. PAS-102, no. 12, pp.3791-3795, Dec. 1983.

[7] S. Arul Daniel and N. AmmasaiGounden"A Novel Hybrid Isolated Generating System Based on PV Fed Inverter-Assisted Wind-Driven InductionGenerators," IEEE Transactions On Energy Conversion, Vol. 19, no. 2, June 2004

[8] W. Xiao, W. G. Dunford, and A. Capel, "A novel modeling method for photovoltaic cells", in Proc. IEEE 35th Annu. Power Electron. Spec. Conf. (PESC), 2004, vol. 3, pp. 1950-1956.

[9] K.H. Hussein, I. Muta, T. Hoshino, M. Osakada, "Maximum photovoltaic power tracking: an algorithm for rapidly changing atmospheric conditions", IEE Proc.Gener. Trans. Distrib., Vol. 142, No. 1, January 1995.

[10] B. G. Dobbs and P. L. Chapman, "A multiple-input DCDC converter topology," IEEE Power Electron. Lett., vol. 1, no. 1, pp. 6-9, Mar.2003.

[11] Khaligh, C. Jian, and L. Young-Joo, "A multiple-input DC-DC converter topology," IEEE Trans. Power Electron., vol. 24, no. 3, pp.862-868, Mar. 2009

[12] S. Bae and A. Kwasinski, "Maximum power point tracker for a multiple-input Ćuk dc-dc converter," Proc. IEEE 31st INTELEC, vol. 20, no. 2, pp. 398-405, Jun. 2005.

[13] R. Zhao and A. Kwasinski, "Multiple-input single ended primary inductor converter (SEPIC) converter for distributed generation applications, "in Proc. IEEE ECCE, 2009, pp. 1847-1854

[14] SungwooBae and Alexis Kwasinski, "Dynamic modelling and operation strategy for a micro grid with wind and photovoltaic resources," IEEE Trans. Smart Grid, vol.3, no.4, pp.1867-1876, May.2012.

[15] Haitham Abu-Rub, Senior Member, IEEE, AtifIqbal, Senior Member, IEEE, Sk.MoinAhmed, Member, IEEE,Fang Z. Peng, Fellow, IEEE, Yuan Li, Member, IEEE, and GeBaoming Member, IEEE "Quasi-Z-Source Inverter-based photovoltaic generation system with Maximum Power Point tracking control using ANFIS," IEEE Transactions on sustainable energy,vol.4, no.1, pp.11-20,May. 2012.

[16] Ansari, S. Chaterjee, and A. Iqbal, "Fuzzy logic control scheme for solar photo voltaic system for maximum power point tracker," Int. J Sustain. Energy, vol. 29, no. 4, pp. 245-255, Apr. 2010.

[17] T. L. Kottas, Y. S. Boutalis, and A. D. Karlis, "New maximum power tracker for PV arrays using fuzzy controller in close cooperation with fuzzy cognitive networks," IEEE Trans. Energy Convers., vol. 21, no.3,pp. 793-803,Sep.2006. 